\title{
Biomass fuel based on wastes from the paper industry
}

\author{
Stanisław Budzyń ${ }^{1}$ and Barbara Tora ${ }^{1, a}$ \\ ${ }^{1}$ AGH University of Science and Technology, Kraków, Poland
}

\begin{abstract}
Wastes from paper industry are mostly combustible. It is possible to recycle them with energy recovery. These wastes have a high moisture content (up to $60 \%$ ) and thus a small calorific value. An alternative to waste incineration is the production of solid recovered fuel. The benefits are: easy adjustment of the physical and chemical properties of the fuel (via the change of proportions of ingredients), low moisture and high calorific value. The study involved the following types of cellulose wastes: - Belmer - the rejects from recovered paper, Krofta - deinking sludge, sludge - wastewater treatment sludge, bark - the rejects from virgin pulps. The results of investigations of waste produced in one of the biggest Polish paper mill - are shown. Following aspects were investigated: energy properties, content of carbon, hydrogen, sulfur, chlorine and nitrogen, chemical composition of ash. Authors proposed two formulas of the biomass fuel. The properties of the fuel such as the content of carbon, hydrogen, sulfur, chlorine or nitrogen, the chemical composition of the ash were investigated. Due to the fact that the combustion of the biomass fuel is preferred in view of law regulations (zero $\mathrm{CO}_{2}$ emission, green certificates) the content of biodegradable fraction was examined. It has been shown that the fuel is a biomass one. Fuel from waste can be a substitute for approx. $25 \%$ of primary fuel (coal) used by the paper mill.
\end{abstract}

\section{Introduction}

Wastes from paper industry are mostly combustible. It is possible to recycle them with energy recovery. These wastes have a high moisture content (up to $60 \%$ ) and thus a small calorific value. An alternative to waste incineration is the production of solid recovered fuel [1]. The benefits are: easy adjustment of the physical and chemical properties of the fuel (via the change of proportions of ingredients), low moisture and high calorific value. The research was carried out in the company International Paper Kwidzyn (Kwidzyn Pulp \& Paper Mill). Following privatization in 1992 the mill at Kwidzyn has gone through a vast modernization program and now occupies a leading position among European and Polish companies [2]. The facility produces office and offset papers. IP also makes Presso ${ }^{\circledR}$ newsprint from deinked wastepaper, while their coated paperboards Arktika and Alaska are widely used in the cosmetics, pharmaceutical and food industry for many household brand names across Europe.

The pulp and paper industry is expected to be a major user of SRF techniques. The impact of this source of wood can best be demonstrated through pulping studies and this procedure has been employed by a number of investigators.

Over the past two decades, increasing environmental awareness has resulted in a much stricter policy with respect to the handling and processing of household and industrial waste. One of the targets of this European Waste Directive is to decrease the amount of waste that

\footnotetext{
a Corresponding author: tora@agh.edu.pl
}

ends up on a landfill. Another result of the increased environmental awareness is the attempt to decrease the burning of fossil fuels with the aim to reduce $\mathrm{CO}_{2}$ emission, and, as a consequence, considerable research effort is directed towards the possibilities of converting waste into solid fuels that are suitable for the replacement of fossil fuels. A solid fuel is a solid material that can be used as fuel to produce energy, such as for example wood, coal or peat.

Several methods for the conversion of waste into solid fuels are known in the art and described in for example US Patent 5302254 and WO 2007/145507 [3]. In US 5302254 a plant for treating industrial and/or urban waste is described, including a stage for drying of the waste, followed by a stage for effecting thermolysis of the dried waste and a stage for effecting recovery of the solids and gases resulting from the thermolysis. Thermolysis of the waste is effected in a reactor by indirect heat exchange with combustion gases. Drying gases for drying of the waste are subsequently treated to remove vapour materials and then recycled to a gas generator for generating the drying gases. Additionally, the plant includes a stage for effecting dechlorination of the solids resulting from the thermolysis by washing the solids with an aqueous liquid, as well as a stage of separating the washed solids and the resulting wash liquid. WO 2007/145507 describes a method for the preparation, by torrefaction, of a solid fuel wherein a starting composition is heated indirectly, and a solid fuel to be obtained by such method. Furthermore, a method for the removal of one or more 
metals from, or the reduction of the "total chlorine content", the sulphur content and the trace element content of a solid fuel thus obtained is disclosed. Also, a solid fuel which can be obtained by the carrying out of such a method and the uses of such solid fuels are described [4].

\section{Materials and method}

The study includes three parts:

- Study the properties of waste from paper mill,

- Technology for the production of secondary fuel (Solid Recovery Fuel)

- Determine the properties of the fuel.

\subsection{Determination of the properties of waste}

The study involved the following types of cellulose wastes [5]:

1. Belmer - waste code 030305 - the rejects from recovered paper are impurities and consist of lumps of fibers, staples and metals from ring binders, sand, glass and plastics and paper constituents as fillers, sizing agents and other chemicals.

2. Krofta - waste code 030310 - deinking sludge. This residue contains mainly short fibers or fines, coatings, fillers, ink particles (a potential source of heavy metals), extractive substances and deinking additives. It is normally reused in other industries (e.g. cement, ceramics), or is incinerated, even though it has a poor heating value)

3. Sludge - waste code 030311 - wastewater treatment sludge. It comes from two sources: primary sludge and biological sludge generated in the second clarifier. These sludges are generally blended together, a polymer added and dewatered together to a $25-40 \%$ dry solid content.

4. Bark - waste code 030301 - the rejects from virgin pulps. It consists of sand, bark and wood residues from wood handling, which are undesirable for papermaking.

The results of investigations of waste produced in one of the biggest Polish Paper Mill - International Paper Kwidzyn are shown. Following aspects were investigated: energy properties, content of carbon, hydrogen, sulfur, chlorine and nitrogen, chemical composition of ash.

\subsection{Investigation of energetic properties of wastes}

The investigations of wastes properties were conducted for their energetic application [6]. The preparation of samples of wastes for research and their analyses were done according to the existing norms concerning analysis of solid fuels. In wastes such parameters were determined: moisture, ash contents, volatile parts contents as well combustion heat and calorific value. Furthermore, coal, hydrogen, sulfur and chlorine contents were determined too. The results are shown in Tables 1 to 5 .

Table 1. Waste balance

\begin{tabular}{|l|l|l|l|l|}
\hline no & $\begin{array}{l}\text { Waste } \\
\text { code }\end{array}$ & $\begin{array}{l}\text { quantity } \\
{[\mathrm{Mg} / \text { year] }}\end{array}$ & yield [\%] & $\begin{array}{l}\text { moisture } \\
{[\%]}\end{array}$ \\
\hline 1 & 030305 & 33000 & 11 & 45 \\
\hline 2 & 030310 & 24000 & 8 & 52 \\
\hline 3 & 030311 & 52000 & 17 & 61 \\
\hline 4 & 030301 & 200000 & 64 & 51 \\
\hline
\end{tabular}

Table 2. Energetic properties of wastes

\begin{tabular}{|l|l|l|l|l|l|l|}
\hline & $\mathrm{W}_{\mathrm{t}}^{\mathrm{r}}$ & $\mathrm{V}^{\mathrm{r}}$ & $\mathrm{A}^{\mathrm{r}}$ & $\mathrm{S}_{\mathrm{t}}^{\mathrm{r}}$ & $\mathrm{Q}_{\mathrm{i}}^{\mathrm{r}}$ & $\mathrm{Q}^{\mathrm{d}}$ \\
\hline $\begin{array}{l}\text { Waste } \\
\text { code }\end{array}$ & {$[\%]$} & {$[\%]$} & {$[\%]$} & {$[\%]$} & {$[\mathrm{kJ} / \mathrm{kg}]$} & {$[\mathrm{kJ} / \mathrm{kg}]$} \\
\hline 030305 & 45,0 & 16,1 & 26,3 & 0,03 & 2107 & 5831 \\
\hline 030310 & 52,0 & 28,1 & 13,3 & 0,03 & 4095 & 11174 \\
\hline 030311 & 61,0 & 20,1 & 15,4 & 0,29 & 2420 & 10022 \\
\hline 030301 & 51,0 & 41,3 & 0,2 & 0,01 & 8500 & 19894 \\
\hline
\end{tabular}

Where:

$\mathrm{W}$ - moisture content,

$\mathrm{V}$ - volatile matter,

A - ash content,

$\mathrm{S}_{\mathrm{t}}$ - sulphur content,

$\mathrm{Q}_{\mathrm{s}}^{\mathrm{a}}$ - calorific value,

$\mathrm{Q}_{\mathrm{i}}^{\mathrm{a}}$ - net calorific value

Table 3. Elements analysis of the waste

\begin{tabular}{|l|l|l|l|l|l|}
\hline & $\mathrm{C}^{\mathrm{a}}$ & $\mathrm{H}^{\mathrm{a}}$ & $\mathrm{Cl}^{\mathrm{a}}$ & $\mathrm{S}^{\mathrm{a}}{ }_{\mathrm{t}}$ & $\mathrm{N}^{\mathrm{a}}$ \\
\hline waste & {$[\%]$} & {$[\%]$} & {$[\%]$} & {$[\%]$} & {$[\%]$} \\
\hline 030305 & 23,2 & 2,26 & 0,03 & 0,04 & 1,42 \\
\hline 030310 & 34,2 & 4,72 & 0,03 & 0,04 & 1,34 \\
\hline 030311 & 30,3 & 4,21 & 0,08 & 0,73 & 4,35 \\
\hline 030301 & 53,1 & 7,06 & 0,01 & 0,01 & 0,08 \\
\hline
\end{tabular}

Table 4. Metals content in ash from waste incineration

\begin{tabular}{|l|l|l|l|l|l|l|l|l|l|l|}
\hline & $\mathrm{Cr}$ & $\mathrm{Cd}$ & $\mathrm{Pb}$ & $\mathrm{Co}$ & $\mathrm{Ti}$ & $\mathrm{As}$ & $\mathrm{Hg}$ & $\mathrm{Sn}$ & $\mathrm{Mn}$ & $\mathrm{Cu}$ \\
\hline waste & {$[\mathrm{mg} / \mathrm{kg}]$} & {$[\mathrm{mg} / \mathrm{kg}]$} & {$[\mathrm{mg} / \mathrm{kg}]$} & {$[\mathrm{mg} / \mathrm{kg}]$} & {$[\mathrm{mg} / \mathrm{kg}]$} & {$[\mathrm{mg} / \mathrm{kg}]$} & {$[\mathrm{mg} / \mathrm{kg}]$} & {$[\mathrm{mg} / \mathrm{kg}]$} & {$[\mathrm{mg} / \mathrm{kg}]$} & {$[\mathrm{mg} / \mathrm{kg}]$} \\
\hline 030305 & 37,22 & 0,01 & 46,73 & 5,79 & 518,61 & 23,49 & 1,32 & 3,32 & 188,58 & 280,81 \\
\hline 030310 & 61,71 & 0,01 & 76,92 & 34,88 & 847,00 & 2,15 & 0,45 & 3,60 & 235,23 & 99,80 \\
\hline 030311 & 48,16 & 8,12 & 51,08 & 7,76 & 710,31 & 10,36 & 1,63 & 7,49 & 1431,32 & 106,06 \\
\hline 030301 & 262,26 & 64,57 & 130,47 & 27,82 & 472,61 & 57,25 & 12,78 & 72,29 & & 926,57 \\
\hline
\end{tabular}

Table 5. Analysis of ash from the waste

\begin{tabular}{|l|c|c|c|c|c|c|c|c|c|}
\hline & $\mathrm{Na}_{2} \mathrm{O}$ & $\mathrm{K}_{2} \mathrm{O}$ & $\mathrm{ZnO}$ & $\mathrm{Fe}_{2} \mathrm{O}_{3}$ & $\mathrm{SiO}_{2}$ & $\mathrm{CaO}$ & $\mathrm{MgO}$ & $\mathrm{Al}_{2} \mathrm{O}_{3}$ & $\mathrm{P}_{2} \mathrm{O}_{5}$ \\
\hline waste & {$[\%]$} & {$[\%]$} & {$[\%]$} & {$[\%]$} & {$[\%]$} & {$[\%]$} & {$[\%]$} & {$[\%]$} & {$[\%]$} \\
\hline 030305 & 0,17 & 0,21 & 0,02 & 0,42 & 26,40 & 60,81 & 1,26 & 9,16 & 0,44 \\
\hline 030310 & 0,20 & 0,32 & 0,05 & 1,08 & 43,20 & 42,23 & 1,15 & 10,69 & 0,60 \\
\hline 030311 & 0,31 & 0,35 & 0,26 & 5,99 & 39,20 & 37,16 & 0,93 & 3,47 & 8,80 \\
\hline 030301 & 0,35 & 4,81 & 0,66 & 2,45 & 22,00 & 48,24 & 10,97 & 1,25 & 8,72 \\
\hline
\end{tabular}


In ash obtained from combustion of wastes samples the basic metal oxides and heavy metals were determined (Table 4, 5). All of wastes indicated high moisture value achieving in case of sewage sludge the value of $70 \%$. The least beneficial waste to energetic application are slimes from discoloration of wastepaper which have the calorific value being equal to $5.8 \mathrm{MJ} / \mathrm{kg}$ in dry conditions. These slimes are $11 \%$ of total mass of wastes directed to combustion with recovery of energy what slightly lower the calorific value of the fuels produced from these wastes. The biggest calorific value have wooden wastes (above $19 \mathrm{MJ} /$ tons in dry condition) and they are $64 \%$ of total mass of wastes. Table 3 presents the sulfur and chlorine contents in wastes in dry condition. Apart from sewage sludge, which contain $0.73 \%$ of sulfur and $0.08 \%$ of chlorine and are $17 \%$ of total mass of wastes, the rest of the wastes characterize with low contents of sulfur (below $0.04 \%$ ) and chlorine (below $0.03 \%$ ).

Table 1 shows the amount of wastes being produced in IP Kwidzyn plant yearly and maximum moisture which these wastes have in initial state. From the data it occurs that about $300000 \mathrm{Mg}$ of fuel can be produced yearly. The moisture in such fuel is higher than $50 \%$ what significantly lowers its calorific value which with this content of moisture is equal to about $7 \mathrm{MJ} / \mathrm{kg}$. For combustion of wastes in such form the delivery of additional energy is required. That is why it is important to elaborate the method of their dewatering what would allow to increase their calorific value and their combustion with recovery of energy.

\subsection{Technology of solid recovery fuel production from wastes}

The best solution of using wastes from celluloid mass and papers which can be combusted with recovery of energy is their complex application to production of secondary fuel [7]. Omitting the issue of biomass contents in researched wastes, according to the current law, the plant IP Kwidzyn can combust these wastes on the area of the plant without applying regulations concerning thermal transformation of wastes. These regulations are not used for installations which transform wastes thermally if these wastes are fibrous, floral from celluloid mass and paper production and if they are combusted in location of production and the produced energy is recovered (Act of Wastes from 14 December 2012, change Bullettin of Acts and Decrees, 2015. 122, article 163). It is also in accordance with the recommendations contained in reference document BAT for paper industry, which states that the best available method of wastes application, which were created during paper production is their combustion with recovery of energy in the location of their origin.

The studies have been carried out in a specially installed at International Paper pilot installation (Scheme of the installation is shown at Figure 1).

Pilot installation uses BELLMER KUFFERATH Machinery. Bellmer Kufferath offers a range of products able to reach the objective targets [2].

Installation for the production of solid recovered fuel consisted of two main stages
- vacuum filter AKSE® F DISC THICKENER,

- filter press AKUPRESS ${ }^{\circ}$ CX-M.

AKSE® $\mathrm{F}$ disc thickeners dewater fibrous materials from a dry content of $0.5-3 \%$ to $5-8 \%$. AKSE® F can be used in various processes either as individual unit or as pre-thickener, e.g. upstream of screw presses. In this case, they help to ensure both the running and the economic efficiency of the screw presses at low solid contents.

AKUPRESS $\AA \quad$ CX-M presses dewater fibrous materials from a dry content of $3 \%$ to $30-55 \%$ and meet all requirements made on fiber dewatering in a very particular way:

- maximum and adjustable dry contents,

- high and adjustable dry contents.

\subsection{Dewatering pilot plant}

Scheme of the pilot plant is shown at Figure 1 . The waste-dewatering pilot plant consists primarily of the following components [8]:

- disk thickener AKSE S 175/01 with flocculation

reactor FR 1 (Serial No. 2000-3190),

- screw press AKUPRESS BX 250 LL (Serial No.

2000-0149),

- metering system for polymeric flocculation media,

- conveyor system for pressed matter,

- container with control cabinet and process control

system WinCC.

Detailed scheme of the pilot installation is shown at Figure 2 and 3.

For transportation, the screw conveyor can be screwed into the base frame as shown in the Figure 3, and can be unscrewed for use according to the diagram (Figure 1).

The system is completely assembled, cased and wired internally. It is delivered on a low loader. The system must be lifted down from the low loader (for the duration of the trials). The total weight without the low loader is 10 tons.

Prior to commissioning, the following external connections must be attached:

- sludge inlet (min. 0.5 bar, DN 50),

- filtrate outlet(DN 100),

- spray water/diluting water for dissolving the

flocculation media (freshwater, 4-6 bar, 2"),

- compressed air (min. 5 bar, $1 / 2 ")$ - only where

available at no cost, otherwise supply from own

compressor,

- electricity $(400 \mathrm{~V}, 50 \mathrm{~Hz}$, connected load $30 \mathrm{~kW}$,

via terminal strip).

Two methods of drying were elaborated in purpose of their application to production of secondary fuel destined to be combusted within the plant.

In first method [6], the technological sewage sludge from mechanical treatment and mechanical and biological treatment as well slimes from discoloration of wastepaper were dewatered by means of the expeller. The attempts of dewatering were conducted on the area of IP Kwidzyn plant by means of installation BELLMER KUFFERATH Machinery. Slimes and sludge were dewatered in two stages, firstly in vacuum filter in purpose of simplifying their dewatering, and then in expeller. The flocculants 
were added to the wastes in purpose of simplifying their dewatering. The dewatered wastes were directed to screw mixer in which the remaining components of secondary fuel can be added (wooden wastes, biomass of agricultural and forest origin).



Figure 1. Block scheme of the solid recovered fuel production.

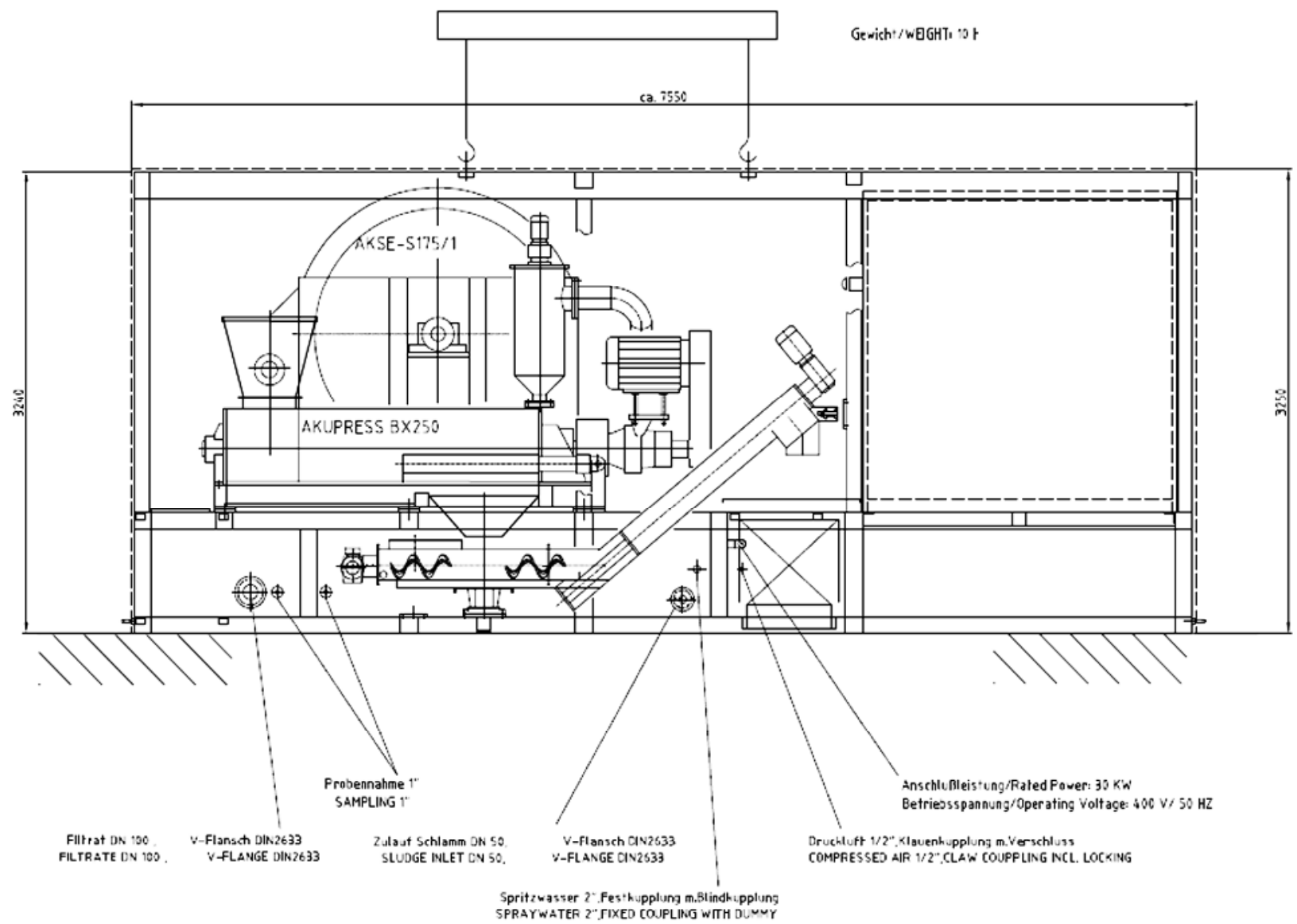

Figure 2. Scheme of the pilot installation. 


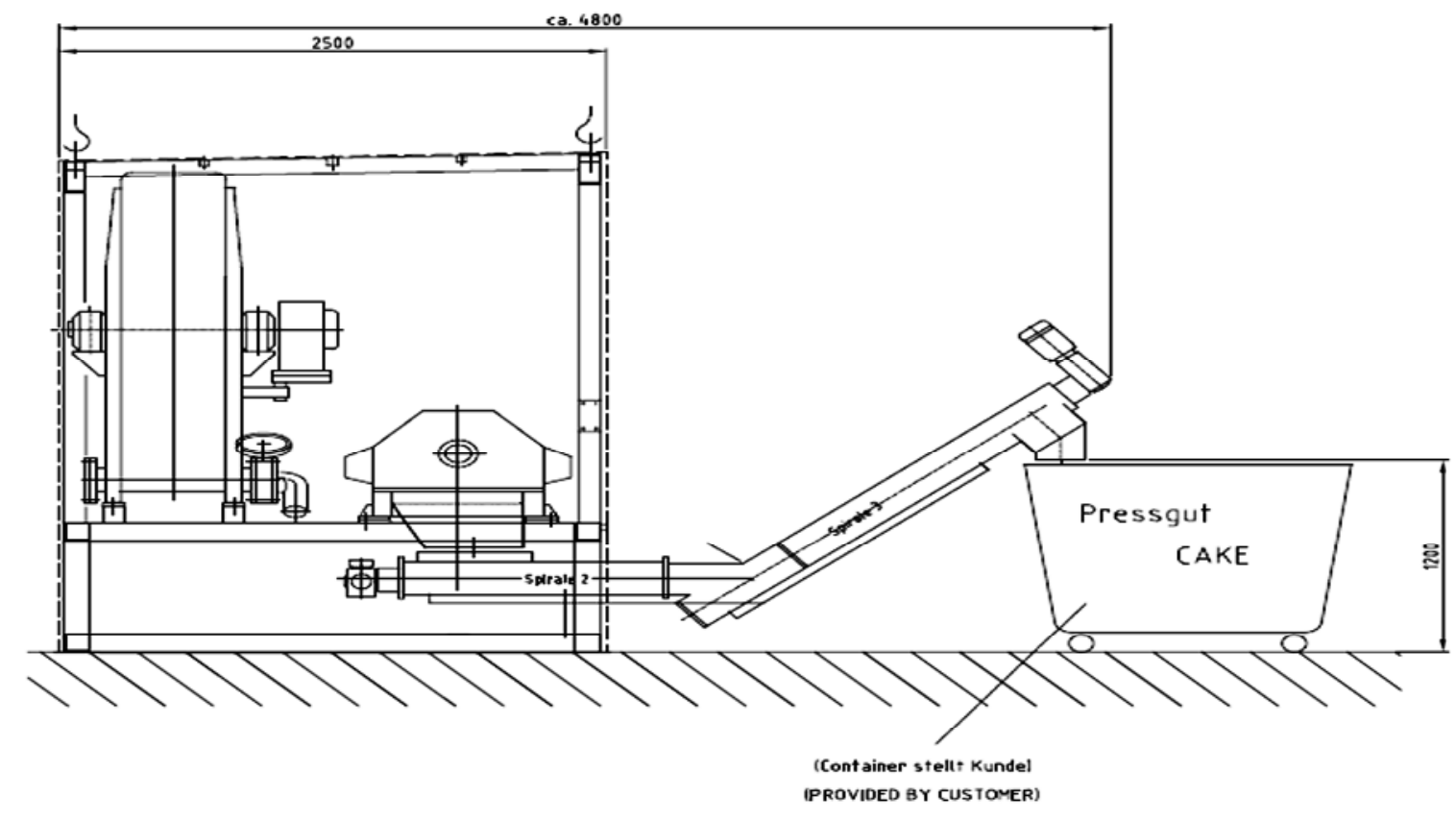

Figure 3. Scheme of the pilot installation - transport by conveyor.

\subsection{Analysis of fuel properties}

From the dewatered wastes two sorts of secondary fuel were produced: fuel P1, in which total using application of sludge and slimes was taken into consideration (wastes $030305,030310,030311$ ) and additionally with 20\% share of wooden wastes (bark, silvers, scobs - waste 030301 ); fuel P2 for which production only fibrous wastes were used $\left(\begin{array}{lll}03 & 03 & 10\end{array}\right)$ and sewage sludge from sewage treatment plant $\left(\begin{array}{lll}03 & 03 & 11\end{array}\right)$. The basic energetic properties of elaborated fuels were presented in Tables 6-9, the coal, hydrogen and nitrogen contents in fuel were presented as well the contents of basic oxides and heavy metals in ash obtained from fuel combustion.

The second method of wastes dewatering from celluloid mass and paper production in IP Kwidzyn plant is based on their drying in drying belt in which the waste heat is used. In this technology the wastes are firstly mixed in mixer before drying.
In the following tables (Table 6-9) the results of Solid Recovery Fuels obtained during the pilot investigations are shown.

Table 6. Properties of SRF

\begin{tabular}{|l|l|l|l|l|l|}
\hline SRF & $\mathrm{W}_{\mathrm{t}}^{\mathrm{r}}$ & $\mathrm{V}^{\mathrm{r}}$ & $\mathrm{A}^{\mathrm{r}}$ & $\mathrm{S}_{\mathrm{t}}^{\mathrm{r}}$ & $\mathrm{Q}_{\mathrm{i}}^{\mathrm{r}}$ \\
\hline & {$[\%]$} & {$[\%]$} & {$[\%]$} & {$[\%]$} & {$[\mathrm{kJ} / \mathrm{kg}]$} \\
\hline P1 & 6,5 & 47,1 & 30,7 & 0,21 & 9759 \\
\hline P2 & 7,5 & 47,2 & 27,2 & 0,2 & 10923 \\
\hline
\end{tabular}

Table 7. Elements analysis of SRF

\begin{tabular}{|l|l|l|l|l|l|}
\hline \multirow{3}{*}{ SRF } & & & & & \\
\cline { 2 - 6 } & $\mathrm{C}^{\mathrm{a}}$ & $\mathrm{H}^{\mathrm{a}}$ & $\mathrm{Cl}^{\mathrm{a}}$ & $\mathrm{S}^{\mathrm{a}}{ }_{\mathrm{t}}$ & $\mathrm{N}^{\mathrm{a}}$ \\
\cline { 2 - 6 } & {$[\%]$} & {$[\%]$} & {$[\%]$} & {$[\%]$} & {$[\%]$} \\
\hline P1 & 30,5 & 3,36 & 0,04 & 0,21 & 1,79 \\
\hline P2 & 32,2 & 3,95 & 0,04 & 0,20 & 1,42 \\
\hline
\end{tabular}

Table 8. Metals content in ash

\begin{tabular}{|l|l|l|l|l|l|l|l|l|l|l|l|}
\hline \multirow{3}{*}{ SRF } & $\mathrm{Cr}$ & $\mathrm{Cd}$ & $\mathrm{Pb}$ & $\mathrm{Co}$ & $\mathrm{Ti}$ & $\mathrm{As}$ & $\mathrm{Hg}$ & $\mathrm{Sn}$ & $\mathrm{Mn}$ & $\mathrm{V}$ & $\mathrm{Cu}$ \\
\cline { 2 - 11 } & {$[\mathrm{mg} / \mathrm{kg}]$} & {$[\mathrm{mg} / \mathrm{kg}]$} & {$[\mathrm{mg} / \mathrm{kg}]$} & {$[\mathrm{mg} / \mathrm{kg}]$} & {$[\mathrm{mg} / \mathrm{kg}]$} & $\begin{array}{l}{[\mathrm{mg} /} \\
\mathrm{kg}]\end{array}$ & $\begin{array}{l}{[\mathrm{mg} /} \\
\mathrm{kg}]\end{array}$ & $\begin{array}{l}{[\mathrm{mg} /} \\
\mathrm{kg}]\end{array}$ & $\begin{array}{l}{[\mathrm{mg} /} \\
\mathrm{kg}]\end{array}$ & $\begin{array}{l}{[\mathrm{mg} /} \\
\mathrm{kg}]\end{array}$ & $\begin{array}{l}{[\mathrm{mg} /} \\
\mathrm{kg}]\end{array}$ \\
\hline $\mathrm{P} 1$ & 36,21 & 2,43 & 42,28 & 5,17 & 227,84 & 4,40 & 0,11 & 4,53 & 448,43 & 56,10 & 222,28 \\
\hline $\mathrm{P} 2$ & 34,12 & 2,63 & 45,83 & 5,43 & 243,58 & 3,14 & 0,10 & 4,27 & 514,29 & 61,40 & 269,28 \\
\hline
\end{tabular}

Table 9. Analysis of ash from SRS incinerating

\begin{tabular}{|l|l|l|l|l|l|l|l|l|l|}
\hline \multirow{2}{*}{ SRF } & $\mathrm{Na}_{2} \mathrm{O}$ & $\mathrm{K}_{2} \mathrm{O}$ & $\mathrm{ZnO}$ & $\mathrm{Fe}_{2} \mathrm{O}_{3}$ & $\mathrm{SiO}_{2}$ & $\mathrm{CaO}$ & $\mathrm{MgO}$ & $\mathrm{Al}_{2} \mathrm{O}_{3}$ & $\mathrm{P}_{2} \mathrm{O}_{5}$ \\
\cline { 2 - 10 } & {$[\%]$} & {$[\%]$} & {$[\%]$} & {$[\%]$} & {$[\%]$} & {$[\%]$} & {$[\%]$} & {$[\%]$} & {$[\%]$} \\
\hline $\mathrm{P} 1$ & 0,29 & 0,25 & 0,11 & 2,53 & 33,40 & 46,38 & 0,82 & 6,95 & 3,42 \\
\hline P2 & 0,28 & 0,30 & 0,11 & 2,76 & 33,50 & 48,86 & 0,86 & 7,2 & 3,73 \\
\hline
\end{tabular}




\subsection{Measurement of the biomass fraction of SRF}

The biomass fraction of SRF has a monetary value under multiple greenhouse gas protocols, such as the European Union Emissions Trading Scheme and the Renewable Obligation Certificate program in the United Kingdom [8]. Biomass is considered to be carbon-neutral since the $\mathrm{CO}_{2}$ liberated from the combustion of biomass is recycled in plants. The combusted biomass fraction of SRF is used by stationary combustion operators to reduce their overall reported $\mathrm{CO}_{2}$ emissions. Several methods have been developed by the European CEN 343 working group to determine the biomass fraction of RDF/SRF. The initial two methods developed (CEN/TS 15440) were the manual sorting method and the selective dissolution method. Since each method suffered from limitations in properly characterizing the biomass fraction, an alternative method was developed using the principles of radiocarbon dating.

A technical review (CEN/TR 15591:2007) outlining the carbon-14 method was published in 2007, and a technical standard of the carbon dating method (CEN/TS 15747:2008) was published in 2008.

In the United States, there is already an equivalent carbon -14 method under the standard method ASTM D6866. Although carbon-14 dating can determine with excellent precision the biomass fraction of RDF/SRF, it cannot determine directly the biomass calorific value. Determining the calorific value is important for green certificate programs such as the Renewable Obligation Certificate program in the United Kingdom. These programs award certificates based on the energy produced from biomass.

Several research papers, including the one commissioned by the Renewable Energy Association in the UK, have been published that demonstrate how the carbon-14 result can be used to calculate the biomass calorific value. Table 10 shows the results of biomass content in fuels from paper wastes.

Table 10. Biomass content in SRF $P 1$ and $P 2$

\begin{tabular}{|l|c|}
\hline SRF & Biomass content [\%] \\
\hline P1 & 67,13 \\
\hline P2 & 87,34 \\
\hline
\end{tabular}

\section{Summary}

Eleven million tons of waste are produced yearly by the European pulp and paper industry, of which 70\% originates from the production of deinked recycled paper.

Due to legislation $[9,10]$ and increased taxes, landfills are quickly being eliminated as a final destination for wastes in Europe, and incineration with energy recovery is becoming the main waste recovery method.

Taking into consideration the data contained in Tables which concern calorific values of individual components and fuel composition considering amount of wastes yearly and their complex application to production of secondary fuel, it is possible to obtain fuel of calorific value from $14-16 \mathrm{MJ} / \mathrm{kg}$.
As a result of conducted investigations of energetic properties of wastes produced from paper production in IP Kwidzyn the technology of secondary fuel production was elaborated, which was made on the basis on slime from discoloration of wastepaper (03 03 05), fibrous wastes, slimes from fibers, fillers and covers originating from mechanical separation $\left(\begin{array}{lll}03 & 03 & 10\end{array}\right)$, sewage sludge from sewage treatment plant $\left(\begin{array}{lll}0 & 03 & 03\end{array}\right)$ and bark (03 0301$)$. It allows to apply these wastes totally to energetic purposes on the area of the plant.

The supplement of the fuel components can be biomass of agricultural or forest origin which can be added in purpose of increasing energetic properties of the fuel.

The pulp and paper manufacturing sector is energy and raw materials intensive, with high capital costs and long investment cycles. The industry has an excellent track record in resource efficiency and innovation. Thanks to its knowledge of wood fibre, the pulp and paper industry is at the forefront of developing innovative products alongside more traditional products. It is a pioneer in making the EU low-carbon bioeconomy an industrial reality.

The manufacturing of Solid Recovered Fuels (SRF) for instance - which can be burned for energy instead of coal, oil and gas - represents an area of great potential. The environmental benefits that the International Paper can achieve from this type of Waste to Energy (WtE) process are numerous, and acknowledgement of these benefits is becoming ever-more widespread. But owners and operators of SRF plants cannot neglect the fact that, whilst supporting the polish;l waste agenda, they are also creating a product to sell to customers such as power stations or cement kilns. These SRF customers need a precise and refined particle size, even more-so than RDF which in comparison tends to be a rougher shred with a less specific fraction requirement. The waste processing systems that recyclers invest in to create SRF should therefore be built and operated in the same way as any true production environment, if both the alternative fuel producer and end user are to reap the greatest possible return on investment. This white paper is designed to offer specialist insight and much-needed guidance for the best practice design and ongoing management of an efficient SRF plant, presented in a five-point plan. Drawing upon the principles of lean manufacturing this paper examines the ways to structure the SRF production system before considering the importance of input material, equipment and operators when creating a high quality fuel for the end user. Challenges do of course face SRF manufacturers but this advice-led resource explains that, when looking at the plant as a production system not just a recycling process, benefits such as maximum availability, uptime, throughput and return on investment can be achieved.

The dewatering of fibrous materials is a fundamental process in the paper and pulp production, but also in all other manufacturing processes using or treating fiber suspensions.

The principal objectives pursued in fiber dewatering may include: 
- separation of water cycles by reducing the dissolved matters in the pressed material ('hydraulic seal');

- the higher the dryness of the thickened stock the higher the efficiency will be:

- increase of the dry content to a value required for downstream processes, e.g. dispersion systems,

- reduction in weight and volume, e.g. for storage and transport.

Due to the large volumes of waste generated, the high moisture content of the waste and the changing waste composition as a result of process conditions, recovery methods are usually expensive and their environmental impact is still uncertain.

Other options such as pyrolysis, gasification, land spreading, composting and reuse as building material are being applied, although research is still needed for optimization of the processes.

\section{References}

1. http://www.spp.pl/the_polish_paper_review.php (2016)

2. http://www.internationalpaper.com/ (2016)

3. M.C Monte., E Fuente., A., Blanco, C. Negro.. Waste Management From Pulp And Paper
Production in the European Union. Chemical Engineering Department. Complutense University of Madrid. (2014).

4. G. Thompson, J. Swain , M. Kay , C.F. Forster., Bioresource Technology, 77, 3, 275-286 (2001)

5. S. Budzyń., W. Andrusikiewicz., V. Cablik., B. Tora, W. Gradon., Journal of the Polish Mineral Engineering Society, 16, 2, 137-141 (2015)

6. B. Tora, S. Budzyń, M. Krzykowski, W. Gradoń, W. Żmuda, Process for the preparation of secondary biomass solid fuel from waste paper industry, Patent PL 402910, Biuletyn Urzędu Patentowego, ISSN 0137-8015, 16, (2011)

7. Integrated Pollution Prevention and Control (IPPC), Reference Document on Best Available Techniques in the Pulp and Paper Industry. European Commission. December. (2001).

8. www.bellmer-kufferath.de (2016)

9. Ustawa z dnia 14 grudnia 2012 r. o odpadach, Dz. U. z 2013 r. poz. 21, (2012)

10. Ustawa $z$ dnia 27 kwietnia 2001 r. Prawo ochrony środowiska, Dz.U. 2001 nr 62 poz. 627. (2011) 